\title{
Bilateral Investment Treaties: Last Resort Strategy to Mitigate Political Risks?
}

\section{Violeta IFTINCHI ${ }^{1}$ \\ Gheorghe HURDUZEU ${ }^{2}$}

\begin{abstract}
Bilateral Investment Treaties (BITs), and in particular the possibility that they offer international arbitration of disputes between the foreign investor and the host country, represent one of the methods that multinational corporations (MNCs) can use as part of their risk management strategy to mitigate political risks.

This article aims to present the constraints identified in using the arbitration procedures of the International Centre for Settlement of Investment Disputes (ICSID): Member States' ignoring arbitration decisions, ICSID's lengthy procedures, calculation of the amount for compensation and the general critics on ICSID arbitration. The article also analyses the effectiveness of BITs compared to the use of other methods to mitigate political risks. The case of Repsol and its expropriation in Argentina is used to demonstrate the presence of those constraints.

The article concludes that MNCs' use of BITs to mitigate political risks in order to protect their foreign investments should be left till last after all other methods have been exhausted.
\end{abstract}

Keywords: political risk, bilateral investment treaties, ICSID, multinational corporations, risk management.

JEL classification: F23, K41, F33.

DOI: $10.24818 /$ RMCI.2018.1.4

\section{Introduction}

Many multinational corporations (MNCs) use bilateral investment treaties (BITs) as a means to protect their investments abroad. BITs are agreements between two countries, a host to a MNC (usually a developing country) and a home to a MNC (usually a developed country) (Elkins, Guzman \& Simmons, 2010; Tienhaara, 2011). In general, BITs include four components: foreign direct investment (FDI) admission, treatment, expropriation and settlement of disputes (Trevino, Thomas \& Cullen, 2008). The number

1 Violeta Iftinchi, Bucharest University of Economic Studies, Institute for Doctoral Studies, International Business and Economics $\mathrm{PhD}$ Programme, Bucharest, Romania, e-mail: violetaiftinchi@gmail.com. The views expressed in this article are those of the author.

2 Gheorghe Hurduzeu, Bucharest University of Economic Studies, Faculty of International Business and Economics, Department of International Business, Bucharest, Romania, e-mail: gheorghe.hurduzeu@rei.ase.ro.

4 Review of International Comparative Management Volume 19, Issue 1, March 2018 
of BITs has significantly increased since the early 1960s. While in 1989 there were only 385 BITs, by the end of 2016 the United Nations Conference on Trade and Development (UNCTAD) counted a total number of 2,957 BITs in operation (UNCTAD, 2017, p. 111).

Molano (2008, p. 18) defines political risk as "the broad spectrum of actions in the political and social environment which can influence a transnational actor's property rights, income or market". Expropriations or nationalisations, transfer and convertibility restrictions, breach of contracts, acts of terrorism, domestic political violence or other adverse regulatory changes and/or government actions are forms of political risks. When political risk targets a specific MNCs, originating from a given country and operating in a particular host country, it is called micro-political risk. According to Alon \& Herbert (2009, p. 130), "micro political risk is defined as the uncertainty associated with outcomes or events from political processes, which have potential and specific consequences for the firm that is either contemplating entry into, or has already entered, another country".

BITs, and in particular the possibility that they offer international arbitration of disputes between the foreign investor and the host country, represent one of the methods that MNCs can use as part of their risk management strategy to mitigate political risks. MNCs often find it essential to resort to using international courts instead of local courts, as local courts have proven to be unsuitable, often lack independence and are under government pressure to settle against the foreign investor (Tienhaara, 2011; Egger \& Merlo, 2012; Clifford Chance, 2012). However, local courts are still critical in enforcing (or declining to enforce) international arbitration awards (Tienhaara, 2011).

BITs contribute to reducing MNCs' political risks in the host country (Egger \& Merlo, 2012) and reassure investors on the willingness of the host country to promote FDI (Desbordes, 2010). They can protect MNCs against political risks like expropriation, theft of intellectual property rights or non-compliance with contractual terms.

Legal arbitration takes place usually through the International Centre for Settlement of Investment Disputes (ICSID) or the UN Commission on International Trade Law (UNCITRAL). ICSID was set up in 1966 and sits as part of the World Bank Group with the purpose of contributing to the World Bank's objective of promoting international investment. ICSID provides facilities for conciliation and arbitration of international investment disputes. In March 2018 it had 162 signatory and contracting states (ICSID, 2018a). Awards in ICSID arbitrations are final and binding, and may not be set aside by the national courts of any Member State (Article 53 and 54 of the ICSID Convention). As of December 2017, ICSID had registered 650 cases under the arbitration and additional facility rules. In $60.6 \%$ of ICSID registered cases the parties used a BIT as a basis for the arbitration request. 49 new ICSID cases were registered in 2017, one case short of the record high of 2015 (ICSID, 2018b). Those statistics show that ICSID remains an important institution for settlement of investor-state disputes and it is clear evidence that foreign investors continue to pursue the resolution of disputes with host countries through international arbitration.

Together with political risk insurance, legal arbitration is considered a last resort strategy (Jensen, 2005; Dupont, Schultz \& Angin, 2016; Gertz, 2017). This is because it confirms the company's failure to prevent political risks. Legal arbitration is used after political risk has already materialised. 
Despite the many benefits of using BITs, even as a last resort, MNCs need to be aware of the constraints that further limit the effectiveness of legal arbitration. Because of the importance of ICSID in the settlement of international Investor-State disputes, the article will focus only on ICSID arbitration. This article aims to present the constraints identified in using ICSID's arbitration procedures: Member States' ignoring arbitration decisions, ICSID's lengthy procedures, calculation of the amount for compensation and the general critics on ICSID arbitration. The article also analyses the effectiveness of BITs compared to the use of other methods to mitigate political risks. The case of Repsol and its expropriation in Argentina is used to demonstrate the presence of those constraints that held back Repsol's attempt in receiving a fair compensation in due time from the Argentinean government and eventually might have forced Repsol to accept an agreement from the Argentinean government and abort the legal arbitration procedures.

On 16 April 2012, the president of Argentina, Cristina Fernández de Kirchner, announced the nationalisation of $51 \%$ of Yacimientos Petroliferos Fiscales (YPF), the former state oil company, belonging to Spain's Repsol and Argentina's largest oil producer. Repsol had a stake of 57.4\%. The Argentinean government intervention made the operation the biggest renationalisation in the natural resources industry since the Russian government took control of Yukos in the early 2000s (Brownlees, 2012). Being targeted to a single firm, Repsol, this case of expropriation is a typical example of a micro-political risk.

In 1999, Repsol acquired YPF for an amount of over USD 15 billion. The company also claimed that it had invested USD 20 billion over 13 years in YPF (Forero, 2012). Following the nationalisation, Repsol also lost USD 1.9 billion of loans that the Eskenazi family's Petersen Energía, the company's partner in the joint-venture, failed to pay. In their exchange, Repsol received the shares pledged as collateral for those loans, thus managing to increase its share in YPF from 6.4\% to 12.4\% (Webber, 2012). Despite the long history and close relationship between Repsol and the Argentinean government, the business climate started to change in November 2011 when the company announced the historic discovery of the shale gas formation of Vaca Muerta ("Dead Cow"). The discovery, estimated to be in the region of 23 billion barrels in natural gas and oil, came at a moment when Argentina was confronted with a domestic energy crisis which transformed the country from a net exporter into a net importer. The Argentinean government argued that the nationalisation was necessary to achieve Argentina's self-sufficiency in the provision of hydrocarbons and therefore of national public interest.

In May 2012, Repsol announced its intention to bring the case for arbitration to ICSID on the basis of a BIT signed between Spain and Argentina in 1991. Under the ICSID procedure, the two parties had six months to negotiate a settlement. As no agreement between Repsol and Argentina was found in that period, in December 2012 Repsol filed a suit at ICSID seeking for USD 10.5 billion in compensation for the nationalisation. The case was registered at ICSID on 18 December 2012 (Repsol, S.A. and Repsol Butano, S.A. v. Argentine Republic - ICSID Case No. ARB/12/38). Apart from the ICSID case, Repsol initiated various legal suits in the US and Spain, including actions against its competitors. On 16 May 2012, Repsol and the investment fund Texas Yale requested (in front of a US federal court) the payment of compensation from the Argentinean government, as it violated the Securities and Exchange Commission

$6 \quad$ Review of International Comparative Management Volume 19, Issue 1, March 2018 
regulations (El País, 2012a). Repsol initiated another case in the court of Madrid for anticompetitive behaviour of YPF which was offering competitors exploitation rights for Vaca Muerta - that has been discovered by YPF prior to the nationalisation (El País, 2012c). Finally, Repsol sued the US company Chevron and the Argentinean company Bridas after they decided to participate in the exploitation of Vaca Muerta.

\section{Member States' ignoring arbitration decisions}

MNCs should be aware that winning an award against a State does not necessarily mean they will receive payment. As Jensen (2005) argues, governments may simply disregard arbitration award decisions, thus leaving investors completely uncovered.

Ignoring the arbitration decisions has been the usual approach taken by Argentina (Johnson, 2012). Argentina has faced far more claims than any other nation because of the numerous cases brought following the Argentinean crisis (1999-2002). In 2010, Argentina was ranked first in the number of cases brought to ICSID with 51 cases. An improvement in Argentina's approach towards arbitration award payment has been observed in the recent years due to the new government's objective to attract new foreign investors. In 2016, Argentina settled a few important ICSID and UNCITRAL arbitration claims and started working on improving the legal framework on commercial arbitration (Vetulli \& Kaufman, 2016).

Argentina argues that the main cause for delay was the fact that claimants had not brought their rulings in front of a local court for collection. Kasenetz (2010) notes that Argentina is promoting the notion that enforcement of ICSID awards is subject to local judicial review as allowed by the terms of the ICSID. In Argentina's interpretation, the ICSID awards must be consistent with their domestic public policy principles. Therefore, local courts have jurisdiction to determine if the awards are unconstitutional, illegal or unreasonable. Argentina has been using this argument in response to a number of claims. Although there may be some good reasoning behind Argentina's approach, it is highly unlikely that this line of reasoning will receive support from other ICSID members.

Moreover, it seems that Argentina's past experience in paying claims show that the government used bonds, and not cash as a final settlement.

The pressure from other ICSID members on Argentina to pay its arbitration penalties had little effect. In response to Argentina's refusal to pay its arbitration awards, the U.S. decided to exclude Argentina from the Generalized System of Preferences (GSP) on 26 March 2012. Argentina failed to pay two US companies that were entitled to compensation following an ICSID arbitration award in 2005 and 2006 (UNCTAD, 2012). Although the economic results of the sanction were not significant (estimations show USD 500 million in exports with tariffs losses of 30 million), the most important was the signal sent by the U.S. authorities. The move to suspend Argentina's access to GSP was the latest effort to push Argentina to respect international arbitration rulings. The European Parliament followed the US example and requested on 20 April 2012 the partial suspension of Argentina from the EU GSP scheme as a response to the YPF's nationalisation (European Parliament, 2012). 


\section{ICSID lengthy procedures}

BITs relevance for risk mitigation is challenged by the lengthy nature of arbitration procedures. This criticism was not only raised for ICSID procedures, but also for arbitration procedures in general (Raviv, 2014). The ICSID average period to obtain the arbitration award is 3.6 years (Kay, 2012), thus Repsol wouldn't have received any payments before 2016. Investors and rating agencies penalised Repsol for relying on this long-lasting procedure to mitigate its political risks. When cutting Repsol rating on 8 June 2012, Fitch was anticipating that Repsol "will not receive any cash compensation from the Argentine government in the short to medium term" (Reuters, 2012).

\section{Calculation of the amount for compensation}

An expropriation event comes with the inherent question: what is the fair compensation that a MNC will receive? (Bremmer \& Keat, 2009). Repsol had calculated an amount of USD 10.5 billion as compensation. The market did not believe that Repsol would receive that amount or any other adequate compensation in the near future (Clifford Chance, 2012). Some analysts estimated in the aftermath of the nationalisation that if any compensation is paid, the amount would not be higher than a quarter of the USD 10.5 billion claimed by Repsol (Brat \& MacDonald, 2012).

As for the outcome of the ICSID case, it would have been interesting to see how the compensation would have been calculated. There was no other case in the ICSID's history where such a high compensation was paid. By the end of May 2017, the highest compensation awarded by ICSID amounted to USD 1.77 billion (decision of 5 October 2012, in the case of Occidental v. Ecuador) (Hodgson \& Campbell, 2017). The largest compensation known in investment treaty arbitration was awarded on 18 July 2014 by an UNCITRAL arbitral tribunal under the auspices of the Permanent Court of Arbitration (PCA) which ordered Russia to pay over USD 50 billion in compensation for the indirect expropriation of the oil company Yukos (Yukos, Veteran and Hulley v Russia (PCA Case No. AA 226).

As for Argentina, the government, very publically and repeatedly, rejected Repsol's claims. Argentina announced that the compensation amount for Repsol will be set by an Argentinean Court (Tribunal de Tasaciones de la Nación), and that it would not be the amount requested by Repsol (El País, 2012b).

\section{General critics on ICSID arbitration}

Experts have also expressed their worries about the arbitration of the World Bank's ICSID which they find sometimes too business-friendly. Critics mention that tribunal members are specialised in commercial arbitration, where disputes are settled based on restricted contract clauses, rather than treaties which involve broader judgements. Moreover, the great majority of ICSID arbitrators are coming from developed countries, which raises concerns over their independence considering that the vast majority of cases are brought by developed countries against developing countries. For instance, almost 70\%

8 Review of International Comparative Management Volume 19, Issue 1, March 2018 
of appointed arbitrators, conciliators and ad hoc committee members in all cases registered and administered by ICSID until December 2017 came from Western Europe and North America (ICSID, 2018b).

Considering the above points Bolivia (2007), Ecuador (2009) and Venezuela (2012) had already withdrew from ICSID. Government officials from Argentina had also threatened to withdraw from ICSID, but ultimately they did not pursue this option. Although the decision of these countries seems to have been triggered by their unwillingness to pay past and potential future claims, other developed countries like Australia considered this option in the past for totally different reasons like preventing foreign investors from invoking investor-state arbitration to challenge Australian sovereignty over public safety, health and the environment. Notably, the Australian government announced in April 2011 that it will no longer include provisions that permit investors to sue governments through international arbitration in its future international trade agreements (Investment Treaty News Quarterly, 2011; Trakman, 2014). At that time, this policy shift was determined partially by the dispute with Philip Morris, the tobacco company, at a tribunal in Singapore over a law standardising cigarette packaging.

In October 2016 ICSID started a process of amending its rules and regulations that tackles some of the constraints and criticisms put forward in this article. The amendments aim at modernising its rules based on case practice and making the process more time and cost effective. Amongst others, the potential areas for amendments include proposals to streamline the process of appointing the arbitrators and the possibility to incorporate a code of conduct for arbitrators in the ICSID process and stricter timeframes for closure of proceedings and issuance of awards. ICSID is currently preparing the background papers that would allow member states to assess the potential changes. Their publication is expected in the first half of 2018 (ICSID, 2017). If implemented, those changes could alleviate some of ICSID's criticism.

\section{How effective are BITs at managing political risks?}

On 27 February 2014, Repsol and the Argentinean government put an end to the controversy originated by the expropriation of YPF by reaching an amiable agreement. Under the terms of the agreement, Argentina recognized a debt to Repsol of USD 5 billion as compensation for the expropriation. In payment of the compensation, Argentina delivered to Repsol a portfolio of sovereign bonds for a total par value of around USD 5.3 billion. These bonds were subsequently sold in their entirety to J.P. Morgan Securities, for a total price of almost USD 5 billion. Moreover, Repsol sold its non-expropriated stake in YPF, a $12.4 \%$, mostly to foreign institutional investors, for the amount of USD 1.3 billion. In the end, Repsol recovered a total amount of USD 6.3 billion of its investment in YPF (Repsol, 2014, p.5). As part of the agreement, Repsol had to drop its legal claims against Argentina and the lawsuits in the United States and Spain against Chevron. Following Repsol's request, ICSID decided on 19 May 2014 the termination of the ICSID procedure against Argentina (ICSID, 2014).

The reasons for accepting this offer which provided Repsol with a compensation representing only half of its investment have not been disclosed. It is likely that Argentina's 
history in ignoring the payment of arbitration claims, ICSID lengthy procedures and the uncertainty related to the amount of compensation played a significant role in Repsol's decision making. Some analysts suggested that Repsol was under pressure to prevent further deterioration of relations between Spain and Argentina (Reed \& Minder, 2014). The agreement seemed to have been beneficial for both parties: it gave Repsol cash to pursue potential acquisitions and helped Argentina in its search for international capital to develop the Vaca Muerta field and other oil and gas fields.

In its risk management strategy to mitigate the risk of expropriation in Argentina, Repsol had used a few methods to pro-actively reduce its political risks. Firstly, it geographically diversified its political risk. Repsol purchased 97.81\% of YPF in 1999 following a privatisation programme and managed to reduce its stake in YPF to 57.4\%. Repsol also reduced the proportion of oil and gas production in Argentina in the company's total production from $72 \%$ in 2002 to just over $50 \%$ of Repsol's total oil and gas production in 2012. Secondly, Repsol used lobbying and advocacy to minimise its political risks in Argentina. The company engaged in lobbying the Argentinean government and relied heavily on the support of Spain and the European Commission to protect its investment in Argentina. Thirdly, Repsol accepted to enter into a "forced" joint-venture agreement with a local company, Petersen Energía. The former president of Argentina, Néstor Kirchner, designed the entry of Petersen Energía into YPF. For Néstor Kirchner it was the solution to bring an Argentinean partner for Repsol and the indigenisation of the company. By 2011 Petersen Energía had acquired 25.5\% stake in YPF under very favourable conditions. None of those methods were successful and the use of ICSID arbitration was a last resort for Repsol.

However, because of the constraints presented in this article, the prospects of receiving fair compensation in due time from the Argentinean government were slim. Even if Repsol had pursued its legal claims, legal arbitration seems to be often perceived as a "noisy divorce", rather than a "friendly separation". According to a 2013 report of the Multilateral Investment Guarantee Agency (MIGA) on world investments and political risk, $45 \%$ of MNCs would use contract renegotiation as the most effective response to a contractual dispute with a State, while only $21 \%$ would make use of international arbitration (MIGA, 2014). 48\% of MNCs mentioned that the key limiting factor that might make contract renegotiation preferable to other dispute resolution methods is because contract renegotiation makes it easier to keep a good business relationship with the host country. The extended time periods until arbitration was ranked only second, with only $15 \%$ of MNCs mentioning it as a limiting factor that might make contract renegotiation preferable.

Keeping a good relationship with a state opens the way for future cooperation. If political and legal environment changes in Argentina, Repsol may be interested in investing again in Argentina in the future. The research carried out by Javalgi, et al. (2011) indicates that permanent exit from a market is not the best strategy for companies struggling for global expansion and pursuing a competitive advantage. Permanent exit from a market is not an optimal strategy for businesses. Therefore, re-entering a market that a MNC had left should be continually re-evaluated in a company's growth and expansion plans.

10 Review of International Comparative Management Volume 19, Issue 1, March 2018 
In the end, Repsol opted for a "friendly separation". Negotiations between Repsol and Argentina on a potential agreement had begun in 2013. The discussions on the final terms started in November 2013 and the governments of Spain and Argentina were both involved in the negotiations and the finalisation of the agreement (Kennedy, 2013).

\section{Conclusions}

Repsol's change of strategy may be proof that once again the use of BITs as a last resort measure by MNCs to mitigate political risks and protect their foreign investments should be left till last after all other methods have been exhausted. This case in point shows that Repsol chose to follow the negotiated path rather than chase lengthy court arbitration. A "friendly separation" should offer MNCs in general the possibility to re-enter a market that they had previously left because of political risks that materialised, for example, expropriation.

However, we should not forget that the primary purpose of BITs is to protect MNCs' assets abroad. When considering the use of BITs and legal arbitration, MNCs should factor in to their decision making process constraints that limit the effectiveness of legal arbitration. This article identified several of those constraints related to ICSID arbitration procedures: Member States' ignoring arbitration decisions, ICSID's lengthy procedures, calculation of the amount for compensation and the general critics on ICSID arbitration. Some of those constraints and criticisms are now subject to a proposal for amendment started by ICSID in 2016. If put into practice, those changes could improve the arbitration process by making it quicker, less costly and more transparent.

\section{References}

1. Alon, I. \& Herbert, T.T., 2009. A stranger in a strange land: Micro political risk and the multinational firm. Business Horizons, 52(2), pp. 127-137.

2. Brat, I. \& MacDonald, A., 2012. Repsol upside is seen after YPF blow. The Wall Street Journal Europe, 2 May p.17.

3. Bremmer, I. \& Keat, P., 2009. The fat tail. New York: Oxford University Press.

4. Brownlees, K., 2012. White paper: Turning tides - The globalisation of political risk. Gallagher London, [online]. Available at: http://www.ajg international.com/assets/Uploads/Publications/TurningTidesWhitePaperJuly2 012.pdf [Accessed 16 February 2013].

5. Clifford Chance, 2012. Resource Nationalism II: Expropriation - Any rights or remedies? Clifford Chance, [online] 1 May. Available at: http://www.cliffordchance.com/publicationviews/publications/2012/05/cliffor d_chance_publicationresourcenationalis.html [Accessed 16 February 2013].

6. Desbordes, R., 2010. Global and Diplomatic political risks and foreign direct investment. Economics \& Politics, 22(1), pp. 92-125. 
7. Dupont, C., Schultz, T. \& Angin, M., 2016. Political Risk and Investment Arbitration: An Empirical Study. Journal of International Dispute Settlement, Oxford, 7(1), pp. 136-160.

8. Egger, P. \& Merlo, V., 2012. BITs Bite: An Anatomy of the Impact of Bilateral Investment Treaties on Multinational Firms. Scandinavian Journal of Economics, 114(4), pp. 1240-1266.

9. El País, 2012a. Repsol demanda a Argentina por violar la ley de mercado de EEUU con YPF. El Pais, [online] 10 July. Available at: http://economia.elpais.com/economia/2012/07/10/agencias/1341922698_8021 14.html [Accessed 2 February 2013].

10. El País, 2012b. Margallo dice que está abierto a reunirse con Argentina para hablar sobre YPF. El Pais, [online] 26 July. Available at: http://politica.elpais.com/politica/2012/07/26/actualidad/1343273356_929736. html[Accessed 2 February 2013].

11. El País, 2012c. Admitida a trámite una demanda de Repsol contra YPF por competencia desleal. El País, [online] 4 October. Available at: http://economia.elpais.com/economia/2012/10/04/agencias/1349351336_3454 36.html [Accessed 2 February 2013].

12. Elkins, Z., Guzman, A. T. \& Simmons, B. A., 2010. Competing for Capital: The diffusion of Bilateral Investment Treaties. In Frieden, J. A., Lake, D. A., Broz, J. L., ed. 2010. International Political Economy: Perspectives on Global Power and Wealth. New York: W.W. Norton.

13. European Parliament, 2012. Resolution on the legal security of European investments outside the European Union. European Parliament, [online] 20 April. Available at: http://www.europarl.europa.eu/sides/getDoc.do?pubRef=//EP//TEXT+TA+P7-TA-2012-0143+0+DOC+XML+V0//EN [Accessed 4 March 2013].

14. Forero, J., 2012. Behind Argentine Seizure, a complex tale. The Washington Post, 26 April p.8.

15. Gertz, G., 2017. Commercial diplomacy and political risk. Global Economy \& Development Working Paper 106, [online]. Available at: http://www.dailymail.co.uk/wires/afp/article-5249135/Macron-visits-

Forbidden-City-China-deals-Xi-talks.html [Accessed 8 January 2018].

16. Hodgson, M. \& Campbell, A., 2017. Study of Cost Awards in Investment Treaty Arbitrations up to 31 May 2017 - Master Table. Allen \& Overy LLP, [online]. Available at: http://www.allenovery.com/SiteCollectionDocuments /Master_Table_Awards_up_to_31_May_2017.PDF [Accessed 16 March 2018].

17. ICSID, 2014. Resolucion procesal dejando constancia de la terminacion del procedimiento de arbitraje. [pdf] Washington, D.C.: International Centre for Settlement of Investment Disputes. Available at: http://icsidfiles.worldbank. org/icsid/ICSIDBLOBS/OnlineAwards/C2684/DC4554_Sp.pdf [Accessed 17 March 2018]. 
18. ICSID, 2017. Amendment of ICSID's Rules and Regulations. [online] International Centre for Settlement of Investment Disputes. Available at: https://icsid.worldbank.org/en/Pages/about/Amendment-of-ICSID-Rules-andRegulations.aspx [Accessed 14 January 2018].

19. ICSID, 2018a. Database of ICSID Member States. [online] International Centre for Settlement of Investment Disputes. Available at: https://icsid.worldbank.org/en/Pages/about/Database-of-Member-States.aspx [Accessed 16 March 2018].

20. ICSID, 2018b. The ICSID Caseload - Statistics (Issue 2018-1). [online] International Centre for Settlement of Investment Disputes. Available at: https://icsid.worldbank.org/en/Documents/resources/ICSID\%20Web\%20Stats \%202018-1(English).pdf [Accessed 16 March 2018].

21. Investment Treaty News Quarterly, 2011. Philip Morris files for arbitration over intellectual property dispute with Australia. Investment Treaty News Quarterly, 2(2), December 2011/January 2012, p. 13.

22. Javalgi, R.G., Deligonul, S., Dixit, A. \& Cavusgil, S.T., 2011. International Market Re-entry: A Review and Research Framework. International Business Review, 20(4), pp. 377-393.

23. Jensen, N., 2005. Measuring Risk: Political Risk Insurance Premiums and Domestic Political Institutions. [pdf] Available at: http://www.sscnet.ucla.edu/ polisci/cpworkshop/papers/Jensen.pdf [Accessed 7 July 2011].

24. Johnson, M., 2012. Repsol's travails remind business of risks. Financial Times: UK edition, 12 June p. 4.

25. Kasenetz, E.D., 2010. Desperate Times Call for Desperate Measures: The Aftermath of Argentina's State of Necessity and the Current Fight in the ICSID. George Washington International Law Review, 41(3), pp. 709-747.

26. Kay, S., 2012. Bilateral investment treaties or political risk insurance? [pdf] Marsh Insights: Political Risk \& Trade Credit, issue VI. Available at: https://usa.marsh.com/Portals/9/Documents/4522\%20MA12-

12062\%20Political\%20Risk\%20and\%20Trade\%20Credit\%20Newsletter.pdf [Accessed 16 February 2013].

27. Kennedy, W., 2013. Repsol to begin talks with Argentina over YPF settlement. Bloomberg, [online] 28 November. Available at: https://www.bloomberg.com/news/articles/2013-11-27/repsol-board-approvessettlement-to-end-ypf-dispute [Accessed 15 March 2018].

28. MIGA, 2014. 2013 World Investment and Political Risk Report. [pdf] Washington, D.C.: The World Bank. Available at: https://www.miga.org/documents/WIPR13.pdf [Accessed 23 March 2016].

29. Molano, W., 2008. Approaches to Political Risk Analysis. In L. D. Howell, $2^{\text {nd }}$ ed. 2008. Political Risk Assessment: Concept, Method and Management. New York: PRS Group, pp. 17-35.

30. Raviv, A., 2014. Achieving a Faster ICSID. Transnational Dispute Management, Special Issue: Reform of Investor-State Dispute Settlement - In Search of A Roadmap, 11(1), pp. 1-49. 
31. Reed, S. \& Minder, R., 2014. Repsol in $\$ 5$ Billion Settlement with Argentina. New York Times, [online] 25 February. Available at: https://www.nytimes.com /2014/02/26/business/international/repsol-said-to-reach-settlement-withargentina.html [Accessed 17 March 2018].

32. Repsol, 2014. Consolidated Management Report for the financial year 2014. [pdf] Available at: https://www.repsol.energy/imagenes/global/en/ Consolidated_management_report_2014_tcm14-14845.pdf [Accessed 14 January 2018].

33. Reuters, 2012. Fitch cuts Repsol, cites Argentine expropriation. Reuters, [online] 8 June. Available at: http://in.reuters.com/article/2012/06/08/repsolfitch-downgrade-idINWNB162320120608 [Accessed 4 March 2013].

34. Tienhaara, K., 2011. Once BITten, twice shy? The uncertain future of 'shared sovereignty' in investment treaty arbitration. Policy and Society, 11(3), pp. 15-21.

35. Trakman, L.E., 2014. Investor-State Arbitration: Evaluating Australia's Evolving Position. The journal of World Investment \& Trade, 15, pp. 152-192.

36. Trevino, L.J., Thomas, D.E. \& Cullen, J., 2008. The three pillars of institutional theory and FDI in Latin America: An institutionalization process. International Business Review, 17(1), pp. 118-133.

37. UNCTAD, 2012. World Investment Report 2012. [pdf] Switzerland: United Nations. Available at: http://www.unctad-docs.org/files/UNCTAD-WIR2012Full-en.pdf [Accessed 16 February 2013].

38. UNCTAD, 2017. World Investment Report 2017. [pdf] Geneva: United Nations. Available at: http://unctad.org/en/PublicationsLibrary/wir2017 _en.pdf [Accessed 18 March 2018].

39. Vetulli, E. \& Kaufman, E. E., 2016. Is Argentina looking for reconciliation with ISDS? Kluwer Arbitration Blog, [blog] 13 October. Available at: http://arbitrationblog.kluwerarbitration.com/2016/10/13/is-argentina-lookingfor-reconciliation-with-isds/ [Accessed 15 March 2018].

40. Webber, J., 2012. Repsol keeps seat on YPF board. Financial Times: UK edition, 5 June p.18. 